\title{
Conceptual Model for Systematic Construction Waste Management
}

\author{
Mohd Hilmi Izwan Abd Rahim ${ }^{1, a}$ and Narimah Kasim² \\ ${ }^{1}$ Department of Construction Management, Faculty of Technology Management and Business, Universiti Tun Hussein Onn Malaysia, 86400 \\ Parit Raja, Batu pahat, Johor Malaysia \\ ${ }^{2}$ Department of Construction Management, Faculty of Technology Management and Business, Universiti Tun Hussein Onn Malaysia, 86400 \\ Parit Raja, Batu Pahat, Johor Malaysia
}

\begin{abstract}
Development of the construction industry generated construction waste which can contribute towards environmental issues. Weaknesses of compliance in construction waste management especially in construction site have also contributed to the big issues of waste generated in landfills and illegal dumping area. This gives sign that construction projects are needed a systematic construction waste management. To date, a comprehensive criteria of construction waste management, particularly for construction project in developing countries such as Malaysia is still not systematically defined. Therefore, construction waste management needs further investigation. This paper aims to explain a concept model for systematic construction waste management in the Malaysian construction industry. The methodology of this paper is through literature and previous research focusing on current practices of construction waste management, the barriers of construction waste management implementation and the additional factor for implementing systematic construction waste management in order to develop a conceptual model. Findings from this study will help to find out the elements required to implement systematic construction waste management in Malaysian construction industry. This action seems significant to the participants in prioritizing construction waste management more systematically. The implementation also will increase the awareness and better understanding of the construction players of the importance of construction waste management in construction projects.
\end{abstract}

\section{Introduction}

The construction industry has contributed to the negative effect of environment. The demand of the construction development especially in developing countries, has generated construction waste [1][2][3][4]. Generally, waste is a substance or item which is discarded or is expected for transfer or is required to be discarded by the procurements of laws [5]. Additionally in another opinion, waste also can be defined as unwanted or discard material produced by households, commercial, institutional and industrial activities [6][7].

Construction waste is a part of waste which can contribute to the environmental issues. Malaysia Solid Waste and Public Cleansing Management Act 2007 (Act 672) stated that the usual method for waste management in Malaysia are through directly disposal into dump or landfills [8][3]. Overall process of construction waste management in the Malaysian construction industry started from waste production in construction site, then all the waste combined and directly disposed into landfill. There is no segregation process in construction site and specialize construction waste landfill in Malaysia [9].

Previous researches had also highlighted, construction waste management practices in Malaysia are improper, which is lack of awareness among the construction parties and increasing number of illegal dumping generated from the construction waste [3][4][10]. It shows the critical construction waste management issues which is increasing year by year. Presently, per capita generation in Peninsular Malaysia is approximately 1.2 $\mathrm{kg}$ of municipal waste (MSW) which amounts to 19,000 tons of waste per day and the figure is set to rise to 30 , 000 tons daily by 2020 , in tandem with the development of country [3][11][9]. The wastes are including construction waste and all waste dumps into same landfill. From the stated data, it shows Malaysian construction industry needs systematic of waste management in order to reduce the number of waste towards the year 2020 .

Additionally, the lack of construction waste management also can contributes negative impact to environmental issues, social and economy [3][4][12]. Unsystematic construction waste management also can contribute to the health and safety issue of construction workers [13]. The unsystematic of construction waste is because of the lack of awareness among the construction parties to manage the construction waste [9][11]. From the statements, it shows Malaysia needs systematic waste management to reduce the number of waste towards the year 2020. Table 1 shows average total of construction waste generated.

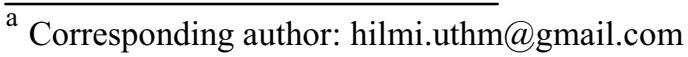


Table 1. Average Total of Construction Waste Generated [9]

\begin{tabular}{|c|c|}
\hline Year & $\begin{array}{c}\text { Total } \\
\text { (Tonne/Daily) }\end{array}$ \\
\hline 2014 & 7.2 \\
\hline 2015 & 28.6 \\
\hline
\end{tabular}

From the data given by SW Corp Malaysia, the critically increasing number of construction waste was generated from year 2014 to 2015 . It shows that there are no reduction in numbers of produced waste from year to year. Several studies have been conducted in various states in Malaysia ranging from year 2004 until 2015 by SW Corp Malaysia [9], showed there are no reduction of construction waste but it increased year by year. Hence, construction waste management is a critical issue have to be emphasized in order to reduce the generated waste in Malaysia. Therefore, this paper is to develop a conceptual systematic model of construction waste management in order to reduce the construction waste management issues.

\section{Literature review}

This section discusses the literature of current practices and trends of construction waste in Malaysia, barriers for implementing construction waste management, and influencing factors for a systematic model on construction waste management.

\subsection{Malaysian construction waste: Trends and current practices}

Rapid development in the construction industry as a result from the expansion of the lifestyle standards, demands of construction, as well as the increasing number of population has positively contributed to increasing number of waste generation [3][14]. Construction wastes are generated by building debris, rubble, earth, concrete, steel, timber and mixed site clearance materials, arising from various construction activities [15]. Construction wastes can be hazardous, for example, asbestos which is generated during demolition of existing structures [16]. Hence, a proper and well defined policy and technologies used in managing wastes produced from the construction activities is required to reduce the adverse effect that can arose on environment, social, and economic aspects. Figure 1 shows the illegal dumping generated from construction project in Malaysia.

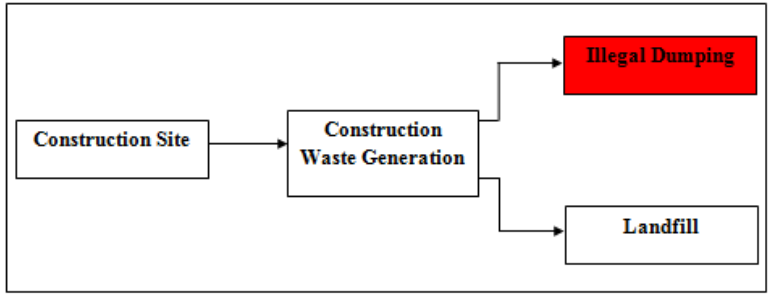

Figure 1. Generation of illegal dumping in construction

Figure 1 shows the current practices of Malaysian construction waste flow which all the waste directly dump into landfill and also the construction waste dump into illegal dump. Hence, the issues of illegal dumping from the construction which are not dumping to the specific landfill [8][3][9]). Furthermore, the information given by SWCorp [9] stated that every year, illegal dumping site increases which is illustrated in Figure 2. In Malaysia, most of the construction site takes the alternative ways to throw their waste to the illegal dumping site. In that case, the attitudes of the person's will contribute to the environmental pollution. Previous research has stated that landfill is the ultimate waste disposal method that can deal with many types of materials [3][17].

Due to this reason, it can be seen in Table 2, the percentage of waste disposed through landfill is increasing proportionally till the targeted year of 2020 . Most of landfills in Malaysia are of small scale operations with varying design. In the light to it, most of the landfills are poorly maintained. Land filling also contributes the highest potentials to global warming [18][19]. Among all the methods used, other disposal sites achieve the highest percentage of waste followed by sanitary landfill whilst the least incineration. Other disposal sites are the open dumpsites that are illegal or have accumulated a large quantity of garbage [20].

\subsection{Barriers for implementing construction waste management}

Malaysia also faces waste problems due to the increasing number construction development [3] [14] Up to the present time, there are many factors contributed to construction waste which were identified from the literature [21-36] as follow:

- Poor site management

- Lack of experience

- Inadequate planning and scheduling

- Mistakes and errors in design

- Incompetent subcontractors

- Rework

- Frequent design changes

- Labour productivity

- Inadequate monitoring and control

- Inaccurate quantity take-off

- Shortage of site workers

- Lack of coordination between parties

- Slow information flow between parties

- Shortage of technical personal (Skilled labor)

- Changes in material specification and type

- Equipment availability and failure 


\section{- Effect of weather}

There are 18 identified factors from the literature. These factors have shown many problems in the construction industry that generated the construction waste. As can be seen from the factors, most of the factors are due of the improper planning, which can be concluded as improper construction waste management. All of these factors contributed to the increasing number of construction waste in the Malaysian construction industry. Therefore, it is important to overcome the factors in order to increase systematic construction waste management in construction project. Additionally the main barriers in generating of construction waste has been grouped into seven main categories based on the literature review [25-32][36]. There are:

- Design - Changes in Design

- Procurement - Ordering errors

- Management - Poor Planning

- Material - Material storage

- Environment - Weather Effects

- Worker - Worker's mistakes

- Site Area - Leftover materials on site

\subsection{Factors influencing construction waste management}

Review of the literature has identified the factors influencing systematic construction waste management. The factors encompass design changes, consideration of reducing construction waste in design, investment on construction waste management, regulation, guidelines, space to perform waste management, adoption of technologies, waste reduction cost and waste management culture within an organization [3][9][14].

\subsubsection{Design changes}

Design changes are one of the influencing factors of systematic construction waste management [28][25][14]. The design change can be identified as an error of construction materials which have been purchased based on the original design. After the design changes has been taken, the material cannot be resold or returned to the supplier or vendor and this situation will contribute to the generation of waste [14].

\subsubsection{Consideration of construction waste reduction in design}

From the previous research [36], it has been reported that approximately $33 \%$ of waste in construction site are related to project design. It shows the big percent contributed to the construction waste is from the early stage of construction. To reduce the generation of waste in construction site, well prepared design stage will directly reduce the possibility of waste generation in construction projects. In order to minimize and proper waste reduction strategies, practices are taken into the design stage such as design for standard size and add the prefabricated or adopting modular [37][38][14].

\subsubsection{Investment in construction waste management}

This factor can help to promote the construction waste management practices among the construction players, stakeholders, and worker in construction site [14]. Additionally, this investment will make workers more responsible to implement the method to control the waste, sorting technique and segregation. At the same time, this factor will motivate the practitioners in the construction industry of the importance to minimize the construction waste.

\subsubsection{Regulation and guidelines}

SWCorp Malaysia, has mentioned in their report the ever increasing number of generated construction waste year by year [9]. In Malaysia, there are no focus or special regulation or guidelines to be followed by the construction industry. In a developed country such as Britain, Australia, Japan, and others country, they have specific guidelines and regulation for construction waste management [3].

Let's have a look at Japan which had adopted an integrated waste and material management approach that promotes dematerialisation and resource efficiency. The government's 'sound material cycle society' initiative launched in 2000 brought with it a number of new regulatory codes including specific laws targeting construction materials [10].

In 2002 Japan introduced the construction waste recycling law, which has resulted in high rates of recycling. For example, $99 \%$ of concrete had been recycled in 2006. The law enforces the recycling of a broad range of construction and demolition materials. Demolition contractors are required to separate and recycle specific construction wastes such as concrete, asphalt, and timber [10]

\subsubsection{Site space for performing waste management}

In developing country, one of the methods for managing the construction waste in site, is to provide space for waste management. Site space refers to the space for sorting and segregation, handling and manage the waste. Sorting at the construction site is widely useful as an effective way in achieving a higher rate of waste reuse and recycling [14][15].

Developed country such as Hong Kong found that given site space as an important factor than the influence of systematic construction waste management [39] Previous study also prove that on site waste sorting could increase the rate of reuse and recycling and directly reduce the logistic cost and dumping cost [39][40][9].

\subsubsection{Adoption of technology}

Use of technologies could help to reduce, reuse or recycle construction waste [14]. The implementation of technologies such as innovation in construction project will contribute to the generation of construction waste. Previous studies proved that the employment of technologies such as prefabrication, IBS, innovation of formwork and others technologies can minimize the 
errors and construction waste being produced [38][41][14][9].

\subsubsection{Waste management culture}

Waste management culture is related to the human behaviour such as awareness of construction parties to get involved in construction waste management [14]. It has been found that the awareness of waste management among practitioners and construction parties can save the resources and protect the environment [42][36][14]. Study has been conducted by [43] for revealing the understanding of both managers and site workers about waste reduction.

Furthermore, in 2006, study done by [36] find out a way for assessing architects' view on the origins of design waste that can minimize the waste design practices in the UK. Finding from this study shows that the awareness and attitudes of the practitioners and construction parties in waste management are big factors that contributes to the reduction of waste management and systematic waste management.

\section{Methodology}

This section describes the methodology adopted throughout the research project. The purpose of this paper is to explain a conceptual model for systematic construction waste management in Malaysia construction industry. Figure 2 shows the methodology for this paper.

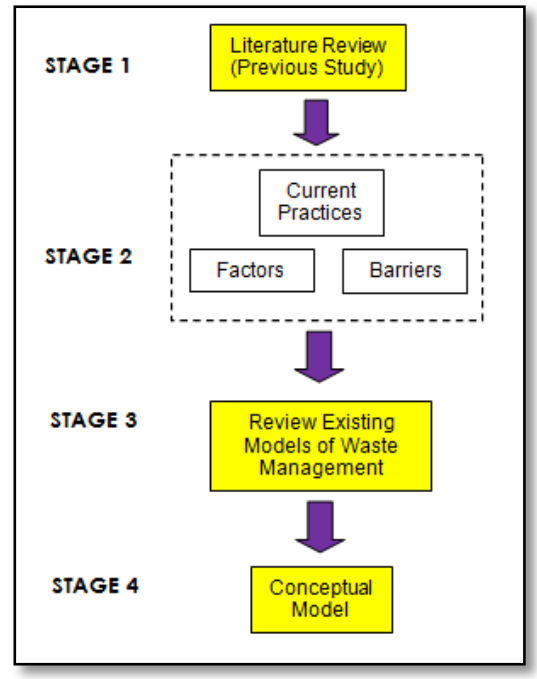

Figure 2. Methodology

The methodology was designed to pursue the aim of this paper as shows in Figure 2, which is to explain a conceptual model for systematic construction waste management in the Malaysia construction industry. Firstly, literature search and previous study was made to review the current practices of construction waste management in Malaysia, the barriers of implementing construction waste management and factors potentially influence the implementation of systematic construction waste management in the Malaysian construction industry.

Next, in stage 2, the elements from the literature review and previous study were analysed to find out the current practices of construction waste management, the barriers of implementing construction waste management and the potential factor in implementing of systematic construction waste management. These three elements are needed to develop a conceptual model in this paper. Stage 3 involved the review process of existing model or related model of construction waste management to find out the similarity between the model and literature. Finally, stage 4 is the process of developing conceptual model. The conceptual model is helpful in improving existing approach of construction waste management in the Malaysia construction industry.

\section{Conceptual model of systematic construction waste management}

The conceptual model is a process, which provides convenient label and categories that helps in explaining and developing detailed description and a coherent analysis of a research. Figure 3 shows the conceptual model for this paper.

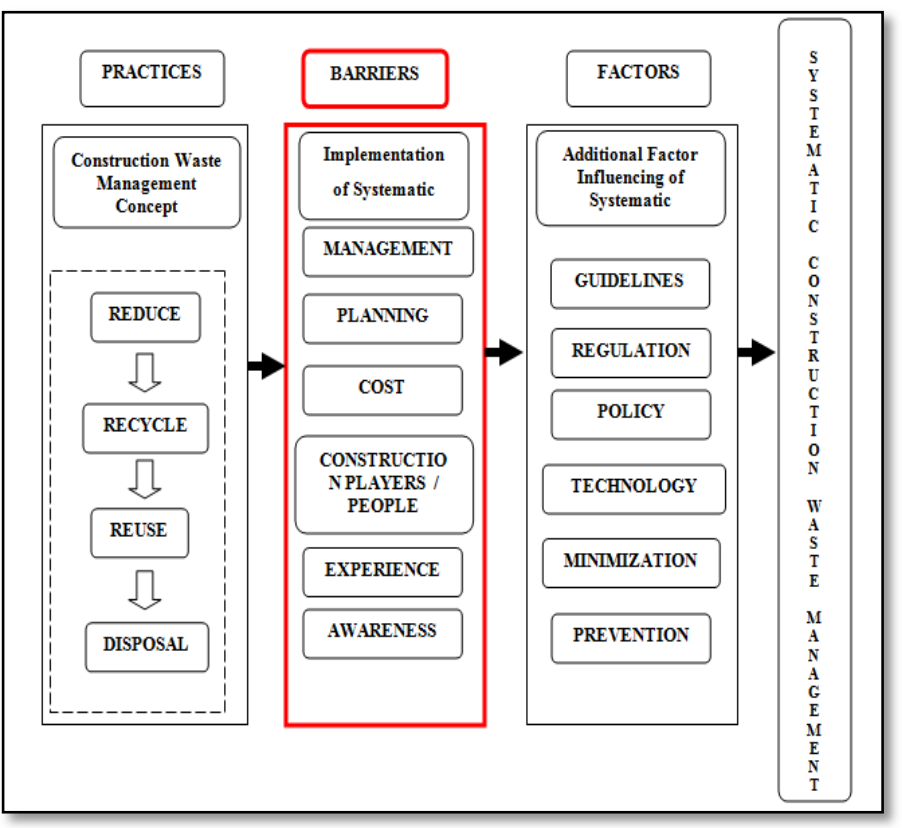

Figure 3. Conceptual model of systematic construction waste management

This paper proposes a conceptual model of systematic construction waste management in the Malaysian construction industry. The conceptual model is developed based on literature review of waste management, construction waste management, construction industry and gap found from the literature. This conceptual model as illustrated in Figure 3 , is to investigate the current practices of waste management, barriers and factor influencing systematic construction waste.

From the literature review, it has been mentioned that most developed country such as the United Stated of America (USA), Australia, Singapore and others had implemented four basic concepts of waste management $[14][32-33][36]$. The four basic concepts of waste management are, reduce, recycle, reuse, and disposal. The four basic concepts as mentioned, come in stages 
which the big portion for implementation is reduce, followed by recycle, then reuse and a small portion for disposal method. But for developing country, it still not clear which practices had been applied. [9], reported that there are no reduction in number of construction waste generation in Malaysia.

Then from the literature, several barriers can be found that hinders the implementation of construction waste management. The barriers are, poor management in construction, improper planning of construction, construction player or people who are involved in construction projects, high of cost, low of experience and lack of awareness among construction parties on the importance of construction waste management. Previous research [20] and [14] mentioned that the lack of awareness among the construction players will contribute to the failure of implementing waste management. Malaysia as a developing country now focuses on construction waste management to reduce the environmental issues. These six major barriers can be dealt with the several factors influencing the implementation of systematic construction waste management.

The factors that influence the implementation of systematic construction waste management are design, guidelines, regulations, investment, technology, reduction and prevention [21-36]. All of these factors will help to improve the current issues on construction waste management and it will produce systematic construction waste management.

\section{Conclusion and recommendation}

It is well recognised that construction waste can be reduced and well managed by a systematic model of construction waste management as proposed in this paper. The purpose of this study is to explain a conceptual model for systematic construction waste management in the Malaysia construction industry. Findings from the literature have found several barriers that influence implementation of construction waste management in the Malaysian construction industry. From the barrier issue, factors influencing implementation of construction waste management was determined.

The most significant factors potentially influencing implementation of systematic construction waste management is design, guidelines, regulation, investment, technology, reduction and prevention. Thus, this ongoing research helps to identify the factors that influence systematic construction waste management. This paper proved that the factors having a strong positive impact to improve the construction waste management in Malaysia construction industry. Additionally these findings will give a better solution to the construction players and increase the awareness among them to implement systematic construction waste management in future construction projects.

\section{Acknowledgement}

The author would like to thank Ministry of Education (MOE), Graduate Students Office Universiti Tun Hussein Onn Malaysia, Department of Construction Management, Faculty of Technology Management and Business, UTHM, for supporting this research. This paper was partly sponsored by the Centre for Graduate Studies UTHM.

\section{References}

[1] Nasaruddin, F.H., Ramli, N.H.M., and Ravana, S.D. 2008, E-Construction waste exchange in malaysia: preliminary study, Proceedings of Information Technology International Symposium 2008, Kuala Lumpur, Malaysia

[2] Siti, N. M., and Noor, Z. M. 2008, Approach in construction industry: A study on prefabrication method as a tool for waste minimization, Proceeding of International Conference on Environmental Research and Technology (ICERT), Penang, Malaysia

[3] Nagapan S., I. A. Rahman, A. Asmi, A. H. Memon, and I. Latif,. (2012). Issues on construction waste: The need for sustainable waste management," 2012 IEEE Colloq. Humanit. Sci. Eng., no. Chuser, pp. 325-330, Dec. 2012.

[4] Seow Ta Wee. (2016). Senario Pengurusan Sisa Pepejal di Malaysia. Penerbit Universiti Tun Hussein Onn Malaysia.

[5] Begum, R. A., Satari, S. K. and Pereira, J. J., (2010). Waste Generation and Recycling: Comparison of Conventional and Industrialized Building Systems. American Journal of Environmental Sciences, 6(4), 383-388.

[6] Ferguson, J., Kermode, N., Nash, C. L., Sketch, W.A.J., and HUxford, R.P. 1995. Minimizing Construction Waste: A Practical Guide. Institute of Civil Engineers, London.

[7] Winkler, G. 2010. Recycling Construction and Demolition Waste. Publisher; McGraw-Hill.

[8] The Ingenieur. 2011. Reduce, reuse and recycle, The Institution of Engineers Malaysia (IEM),

[9] SWCorp Malaysia. 2015. Progress Report 2015. SWCorp Malaysia. 
[10] Ismam, J. N. and Ismail, Z. 2014. Sustainable Construction Waste Strategic Implementation Model. WSEAS Transactions on Environment and Development. ISSN:2224-3496. Vol. 10.

[11] Sreenivasan J., Marthandran G., and Malarzhi C. A. N. 2012. Domestic Solid Waste Minimization in Malaysia-A Behavioural Study. Faculty of Management Multimedia University.Konstantakopoulou, E., RodriguezCarmona M., and Barbur J. L. 2012. Processing of Color Signals in Female Carriers of Color Vision Deficiency. Journal of Vision. 12(2): 1-11.

[12] Udawarta, N., Zuo. J., Chiveralls, K., and Zillante, G. 2015. Improving waste management in construction projects: an Australian study. Elsievier 101 (2015) 73-83.

[13] Seow, T. W. \& Mohamad, A. H. 2007. Pengurusan Sisa Pembinaan Di Tapak Binaan. Retrieved on March 20, 2012.

[14] Yuan, H. 2013. Key indicators for assessing the effectiveness of waste management in construction projects. Ecological Indicators 24(2013) 476-484.

[15] Shen, L. Y., Hao, J. L., Tam, V. W. Y., and Hou, H. 2007. A checklist for assessing sustainable performance of construction project. J. Civil Eng. Manage. 13(4), 273-281. Augmented Reality. Massachusetts: A K Peters.

[16] Hassan, M.N. 2002. Solid waste management in Malaysia: can we charter future strategies? In: Proceedings of International Conference Environmental Management: Ten Years after Rio. Article Number 8. Universiti Putra Malaya. 2002.

[17] Lau, V.L. 2004. Case study on the management of waste materials in Malaysia. Forum Geookol. 15(2). 2004.

[18] Piyaphant, S. and Prayong, K. 2011. Environmental impact on municipal solid waste management system in Chaiyaphum. in Proceedings of the 10th WSEAS international conference on System science and simulation in engineering, 2011, pp. 213-218.

[19] Sakawi, Z. 2011. Municipal solid waste management in Malaysia: Solution for sustainable waste management. Journal of Applied ciences in Environmental Sanitation. Vol 6. ISSN 0126-2807.

[20] Manaf, L.A., Samah, M.A.A,. 2009. Municipal Solid Waste Management in Malaysia: Practices and Challenges . Waste Management. 29:2902-2906
[21] Nazech E.M, Zaldi D., and Trigunarsyah B. 2008. Identification of Construction Waste in Road and Highway Construction Projects. Eleventh East AsiaPacific Conference on Structural Engineering \& Construction (EASEC-11), Taiwan, (2008), pp.19-21.

[22] Serpell, A., Venturi, A., and Contreras, J. 1995. Characterization of waste in building construction projects. Presented on the 3rd workshop on lead construction, Albuquerque, pp. 67-77.

[23] Senaratne, S., and Wijesiri, D. 2008. Lean Construction as a Strategic Option : Testing its Suitability and Acceptability in Sri Lanka. Lean Construction Journal, pp. 34-48.

[24] Wahab, A. B., and Lawal, A. F. 2011. An evaluation of waste control measures in construction industry in Nigeria. African Journal of Environmental Science and Technology, Volume 5, pp. 246-254.

[25] Ekanayake, L. L., and Ofori, G. Construction material waste source evaluation. Proceedings of Strategies for a Sustainable Built Environment, Pretoria, (2000).

[26] Alwi, S., Hampson, K., and Mohamed, S. 2002. Non Value-Adding Activities in Australian Construction Projects.

[27] Zhao, Y., and Chua, D. K. H. 2003. Relationship between productivity and non value-adding activities.

[28] Faniran, O. O., and Caban, G. 2007. Minimizing waste on construction project sites. Engineering Construction and Architectural Management Journal, Volume 5(1), pp.182-188.

[29] Polat, G., and Ballard, G. 2004. Waste in Turkish Construction: Need for Lean Construction Techniques. Proceeding 12th Annual Conference of the International Group for Lean Construction (IGLC-12), Elsinore.

[30] Formoso C. T., Isatto E. L. and Hirota E. H. 1999. "Method for Waste Control in the Building Industry", Proceedings of the Seventh Annual Conference of the International Group for Lean Construction, Berkeley.

[31] Alwi, S., Hampson, K. and Mohamed, S. 2002. Waste in the Indonesian construction projects. Proceedings of International Conference of CIB W107 - Creating a sustainable Construction 
Industry in Developing Countries, South Africa, pp. 305-315.

[32] Gavilan, R. M. and Bernold, L. E. 1994. Source evaluation of solid waste in building construction. Journal of Construction and Management, pp. 536552.

[33] Lu, W., Yuan, H., Li, J., Hao, J. J. L., Mi, X., and Ding, Z. 2011. An empirical investigation of construction and demolition waste generation rates in Shenzhen city, South China. Waste management, Volume 31(4), pp. 680-687.

[34] Wang, J. Y., Kang, X. P., and Tam, V. W. Y. 2008. An investigation of construction wastes: an empirical study in Shenzhen. Journal of Engineering, Design and Technology, Volume 6(3).

[35] Wan, K. M. S., Kumaraswamy, M. M. and Liu, D. T. C. 2009. Contributors to Construction Debris from Electrical and Mechanical Work in Hong Kong Infrastructure Projects. Journal of Construction Engineering and Management, Volume 135(7), pp. 637-646.

[36] Osmani, M., Glass, J., Price A.D.F. 2008. Architects' perspectives on construction waste reduction by design. Journal of Waste Management, Volume 28, pp. 1147-1158.

[37] Innes, S. 2004. Developing tools for designing out waste pre-site and on-site. Proceeding of minimizing construction waste conference: Developing Resources Efficiency and Waste Minimisation in Design Construction. London.

[38] Jaillon, L., Poon, C.S., and Chiang, Y.H. 2009. Quantifying the waste reduction potential of using prefabrication in building construction in Hong Kong. 29(1), 309-320.

[39] Poon, C.S., Yu, A.T.W., and Ng, L.H. 2001. On-site sorting of construction and demolition waste in Hong Kong. 32(2), 157-172.

[40] Hao, J.L., Hills, M.J., and Shen, L.Y. 2008. Managing construction waste on site through system dynamic modeling: The case of Hong Kong. 15(2), 103-113.

[41] Esin, T., and Cosgun, N. 2007. A study to conducted reduce construction waste generation in Turkey. Build Environment. 42(4) 1667-1674.
[42] Yuan, H.P., and Shen, L.Y. 2011. Trend of the research on construction and demolition waste management. Waste manage 31, 670-679.

[43] Lingard, H., Graham, P., and Smithers, G. 2000. Employee perception of the solid waste management system operation in a large Australia contracting organisation implication for company 